\title{
GUI MATLAB UNTUK METODE FUZZY SAW DAN FUZZY TOPSIS DALAM PEMILIHAN PENERIMA BEASISWA PPA DENGAN PEMBOBOTAN ENTROPI (Studi Kasus : Pemilihan Penerima Beasiswa PPA tahun 2017 Mahasiswa FSM UNDIP, Semarang)
}

\author{
Ratna Rahmaniar ${ }^{1}$, Tatik Widiharih ${ }^{2}$, Dwi Ispriyanti ${ }^{3}$ \\ 1,2,3 Departemen Statistika, Fakultas Sains dan Matematika, Universitas Diponegoro \\ e-mail :widiharih@gmail.com
}

\begin{abstract}
For students, scholarships are important to ease the burden on parents, namely tuition fees. The large number of scholarship applicants is a challenge for FSM to be able to provide an appropriate, effective and efficient decision to manage data on scholarship recipients who are truly entitled to receive scholarships. Prospective scholarship recipients are selected based on the criteria determined by FSM.The criteria determined by the FSM are GPA (Grade Point Average), parent income, number of certificates, number of dependents of parents, semester, and electricity. The method applied to select 170 PPA scholarship recipients (Academic Achievement Improvement) is FSAW (Fuzzy Simple Additive Weighting) and FTOPSIS (Fuzzy Technique for Order Preference by Similarity to Ideal Solution) with entropy weighting. This entropy weighting does a combination of the initial weight that has been determined by FSM and the calculation weight. This research was conducted with the help of MATLAB (Matrix Laboratory) GUI (Graphical User Interface) as a computing tool. With the MATLAB GUI system built, it can simplify and speed up the selection process. FSAW and FTOPSIS calculation results are $96 \%$ the same, while FSAW with FSM is only $39 \%$ the same and FTOPSIS with FSM is only $42 \%$ the same.The FSAW and FTOPSIS methods are better used than the determination of the FSM, because the results of the FSM are not appropriate.FSM selects manually by looking at files collected by registrants.
\end{abstract}

Keywords:Scholarship, FSAW, FTOPSIS, Entropy, GUI

\section{PENDAHULUAN}

Dalam meraih pendidikan diperlukan adanya biaya.Mahasiswa yang kurang dalam segi ekonomi maka memerlukan beasiswa.Beasiswa adalah bantuan untukmembantu orang terutama bagi yang masih kuliah agar merekadapat menyelesaikan tugasnya dalam rangka mencari ilmu pengetahuanhingga selesai.Pemerintah melalui Direktorat Jenderal Pembelajaran dan Kemahasiswaan berupaya mengalokasikan dana untuk memberikan bantuan biaya pendidikan kepada mahasiswa yang orang tuanya tidak mampu membiayai pendidikannya dan memberikan beasiswa kepada mahasiswayang mempunyai prestasi di bidang akademik atau non akademik.

Fakultas Sains dan Matematika (FSM) Undip sebagai pelaksana berbagai macam beasiswa salah satunya adalah beasiswa Peningkatan Prestasi Akademik (PPA.Beberapa kriteria yang digunakan untuk menentukan beasiswa antara lain : IPK, penghasilan orang tua, jumlah sertifikat yang dimiliki, jumlah tanggungan orang tua, semester, daya listrik yang digunakan.Penyeleksian yang dilaksanakan oleh FSM masih secara manual maka dalam proses pelaksanaannya terdapat beberapa hambatan. Hambatan yang dihadapi adalah banyaknya mahasiswa yang mendaftar dan syarat-syarat yang diberikan cukup banyak.Syarat-syarat yang dimaksud adalah banyaknya berkas yang harus disiapkan untuk mendaftar beasiswa. Akibatnya, proses penyeleksian sering terjadi banyak kesalahan dan memakan banyak waktu, maka diperlukan metode untuk mengolah data yang diperlukan dalam proses penyeleksian penerimaan mahasiswa dan menghasilkan suatu keputusan kriteria mahasiswa yang berhak atau tidak menerima beasiswa. Salah satu metode statistika yang digunakan untuk menyeleksi mahasiswa yang berhak menerima beasiswa adalah FuzzyMulti Attribute Decision Making (FMADM). 
Fuzzy Multi Attribute Decision Making (FMADM) adalah pengembangan dari MADM untuk pengambilan keputusan terhadap beberapa alternatif untuk mendapatkan suatu keputusan yang lebih akurat dan optimal.Inti dari FMADM adalah menentukan nilai bobot untuk setiap atribut, kemudian dilanjutkan dengan proses perankingan yang akan menyeleksi alternatif yang sudah diberikan.FuzzyTechnique for Order Preference by Similarity to Ideal Solution (FTOPSIS) dan FuzzySimple Additive Weighting (FSAW) yang dimaksudkan disini untuk perhitungannya sama dengan TOPSIS dan SAW pada umumnya, bedanya setiap variabel diubah dalam bilangan fuzzy. Bilangan fuzzy biasanya diekspresikan secara linguistik (kata-kata) mudian diubah ke bentuk bilangan.Bilangan fuzzy didefinisikan yaitu berada dalam interval tertutup untuk setiap $0 \leq \alpha \leq 1$.

Pembobotan untuk kasus ini yaitu menggunakan pembobotan entropi. Pembobotan entropi digunakan untuk menghitung suatu bobot pada kriteriadengan variasi nilai tertinggi akan mendapatkan bobot tertinggi (Triyanti dan Gadis, 2008).Dengan pembobotan entropi, peneliti juga bisa mengkombinasikan hasil bobot perhitungan dengan bobot yang telah ditentukan oleh penyeleksi pada tiap kriteria.

Penelitian ini membahas tentang penyeleksian penerima beasiswa PPA untuk mahasiswa FSM UNDIP tahun 2017 menggunakan metode FSAW dan FTOPSIS dengan pembobotan entropi.

\section{TINJAUANPUSTAKA}

\subsection{Pengertian Beasiswa}

Beasiswa adalah pemberian berupa bantuan keuangan yang diberikan kepada mahasiswa yang digunakan demi keberlangsungan pendidikan yang ditempuh. Pemberianbeasiswa dapat dikategorikan pada pemberian cuma-cuma ataupun pemberian dengan ikatan kerja (biasa disebut ikatan dinas) setelah selesainya pendidikan (Ariyadi, 2013).

\subsection{Beasiswa di Fakultas Sains dan Matematika}

Terdapat salah satu beasiswa yang diberikan oleh Fakultas Sains dan Matematika (FSM) adalah Beasiswa Peningkatan Prestasi Akademik (PPA).Beasiswa Peningkatan Prestasi Akademik (PPA) merupakan salah satu beasiswa sumber dananya diperoleh dari Kementrian Riset, Teknologi dan Pendidikan Tinggi (Kemenristek Dikti) dan dialokasikan untuk mahasiswa yang memiliki prestasi dibidang akademik berupa nilai IPK yang baik maupun prestasi dibidang non akademik berupa piagam penghargaan.

\subsection{Kriteria Pemilihan Penerima Beasiswa PPA}

Kriteria-kriteria untuk mendapatkan beasiswa PPA di FSM yaitu:

\section{Indeks Prestasi Kumulatif (IPK)}

IPK untuk syarat mendaftar beasiswa PPA yaitu minimal 3.0.

\section{Penghasilan/Gaji/Upah Orang Tua}

Penghasilan orang tua yang di syaratkan untuk mendaftar beasiswa PPA tidak ada minimal gajinya.Berapapun penghasilan orang tua boleh untuk mendaftar dan yang dipilih untuk penerima beasiswa PPA itu penghasilan orang tua berbeda-beda.

\section{Sertifikat/Piagam}

Sertifikat yang disyaratkan untuk mendaftar beasiswa PPA itu sertifikat yang diperoleh pada saat berada di perguruan tinggi.Semakin banyak sertifikat yang diperoleh mahasiswa pendaftar, kemungkinan untuk mendapatkan beasiswa PPA itu besar walaupun nilai IPK nya tidak terlalu tinggi. 


\section{Tanggungan orang tua}

Semakin banyak jumlah anggota keluarga semakin besar juga biaya hidup sebuah keluarga tersebut.

\section{Semester}

Syarat mahasiswa pendaftar beasiswa PPA itu minimal harus sudah menempuh semester 2, dikarenakan saat semester itu sudah memperoleh nilai IPK.

\section{Daya listrik}

Syarat daya listrik untuk mendaftar beasiswa PPA tidak ada maksimal atau minimal ukurannya, namun yang sebagai bahan pertimbangan adalah ukuran paling rendah.

\subsection{Populasi, Sampel dan Teknik Sampling}

Menurut Sugiyono (2010), populasi adalah wilayah generalisasi yang terdiri atas: objek/subjek yang mempunyai kualitas dan karakteristik tertentu yang ditetapkan oleh peneliti untuk dipelajari kemudian ditarik kesimpulannya.Sampel menurut Arikunto (2006: 131), adalah sebagian atau wakil populasi yang diteliti.Pengertian teknik sampling menurut Sugiyono (2001), adalah teknik pengambilan sampel (Sugiyono, 2001: 56).

\subsection{Pembobotan Entropi}

Pembobotan entropi menyelidiki keserasian dalam diskriminasi diantara sekumpulan data.Sekumpulan data nilai alternatif pada kriteria tertentu digambarkan dalam Decision Matrix(DM).Metode ini tidak mensyaratkan satuan maupun range dari setiap kriteria harus sama, karena sebelum diolah semua data akan dinormalisasi dahulu sehingga akan bernilai antara 0-1 (Triyanti dan Gadis, 2008).Langkah-langkah untuk menentukan suatu bobot dengan metode ini adalah sebagai berikut:

1. Membuat tabel Descision Matrix (DM)

Dalam permasalahan ini, semua data alternatif terhadap masing-masing kriteria terlebih dahulu diubah ke dalam data fuzzy.Descision Matrix (DM) yaitu :

$$
\boldsymbol{X}=\left[\begin{array}{cccc}
x_{11} & x_{12} & \ldots & x_{1 n} \\
x_{21} & x_{22} & \ldots & x_{2 n} \\
\vdots & \vdots & & \vdots \\
x_{m 1} & x_{m 2} & \ldots & x_{m n}
\end{array}\right]
$$

dengan $: i=1,2, . . m ; j=1,2, . . n ; x i j$ merupakan rating kinerja alternatif ke-i terhadap kriteria ke-j.

2. Normalisasi tabel rating kecocokan

Nilai setelah dilakukan normalisasi akan memiliki nilai dari 0 hingga 1.Rumus normalisasi adalah sebagai berikut :

$$
d_{i j}=\frac{x_{i j}}{\max _{i}\left(x_{i j}\right)}
$$

Sehingga didapatkan matriks ternormalisasi $\mathbf{D}$ dengan bentuk sebagai berikut:

$$
\boldsymbol{D}=\left[\begin{array}{ccc}
d_{11} & d_{12} \cdots & d_{1 n} \\
d_{21} & d_{22} \cdots & d_{2 n} \\
\vdots & \vdots \vdots & \vdots \\
d_{m 1} & d_{m 2} \cdots & d_{m n}
\end{array}\right]
$$

Selanjutnya nilai masing-masing data alternatif terhadap kriteria yang telah dinormalisasi seperti pada persamaan (3) dijumlahkan.

$$
D_{j}=\sum_{i=1}^{m} d_{i j} ; \mathrm{j}=1,2, \ldots, \mathrm{n}
$$


3. Perhitungan entropi

Perhitungan entropi untuk setiap kriteria ke-j dengan terlebih dahulu menghitung nilai emax dan $\mathrm{K}$. Untuk mencari nilai emax dan $\mathrm{K}$ yaitu :

$e_{\max }=\ln \mathrm{m} ; \mathrm{m}$ adalah jumlah alternatif

$$
K=\frac{1}{e_{\max }}
$$

Perhitungan entropi untuk setiap kriteria ke-j

$\mathrm{e}\left(d_{j}\right)=-K \sum_{i=1}^{m} \frac{d_{i j}}{D_{j}} \ln \frac{d_{i j}}{D_{j}} \quad \mathrm{~K}>0$

Selanjutnya menghitung total entropi $(\mathrm{E})$

$E=\sum_{j=1}^{n} e\left(d_{j}\right)$

4. Perhitungan bobot entropi

- Jika sebelumnya tidak ada bobot awal kriteria yang sudah ditentukan oleh pelaksana, maka menghitung bobot entropi untuk setiap kriteria.

$$
\begin{aligned}
& \bar{\lambda}_{\mathrm{j}}=\frac{1}{n-E}\left\{1-e\left(d_{j}\right)\right\}, 0<\lambda_{j}<1 \\
& \sum_{j=1}^{n} \bar{\lambda}_{\mathrm{j}}=1
\end{aligned}
$$

- Jika sebelumnya ada bobot awal kriteria yang sudah ditentukan oleh pelaksana, maka hasil bobot entropi untuk tiap kriteria.

$$
\lambda_{j}=\frac{\bar{\lambda}_{\mathrm{j}} \cdot w_{j}}{\sum_{j=1}^{n} \bar{\lambda}_{\mathrm{j}} \cdot \mathrm{w}_{\mathrm{j}}} ; \mathrm{j}=1,2, \ldots, \mathrm{n}
$$

dengan: $\lambda_{j}=$ bobot entropi akhir; $\mathrm{n}=$ jumlah kriteria $; w_{j}=$ bobot awal

\subsection{Fuzzy Multi Atribute Decission Making (FMADM)}

Metode FMADM merupakan pengembangan lebih lanjut dari MADM.Penerapan logika fuzzy dalam MADM, yang selanjutnya disebut sebagai FMADM.Menurut Kusumadewi dkk.(2006), Fuzzy Multi Atribute Decission Making(FMADM) adalah suatu metode yang digunakan untuk mencari alternatif optimal dari sejumlah alternatif dengan kriteria tertentu.Salah satu mekanisme untuk menyelesaikan masalah FMADM dengan mengaplikasikan metode MADM klasik seperti SAW, WP, atau TOPSIS.

\subsection{Fuzzy Simple Additive Weighting (FSAW)}

Metode FSAW sama dengan metode SAW pada umumnya hanya saja bedanya di dalam FSAW data awal itu diubah ke dalam bilangan fuzzy. Menurut Fishburn, 1967 dan MacCrimon, 1968 dalam Kusumadewi dkk. (2006), metode SAW juga sering dikenal dengan istilah metode penjumlahan terbobot.Menurut Kusumadewi dkk. (2006), langkah penyelesaian dalam menggunakan metode FSAW sebagai berikut:

1. Membuat matriks keputusan (X) yang sudah diubah dalam data fuzzy, seperti pada persamaan (1).

2. Melakukan normalisasi matriks keputusan sebagai berikut:

$$
\begin{aligned}
& r_{i j}=\frac{x_{i j}}{\max _{i}\left(x_{i j}\right)}(\text { atributbenefit/keuntungan }) \\
& r_{i j}=\frac{\min _{i}\left(x_{i j}\right)}{x_{i j}}(\text { atributcost/biaya })
\end{aligned}
$$

3. Hasil akhir nilai preferensi $\left(V_{i}\right)$.

$$
V_{i}=\sum_{j=1}^{n} \lambda_{\mathrm{j}} \times r_{i j}(13)
$$

Nilai $V_{i}$ terbesar mengindikasikan bahwa alternatif $A_{i}$ merupakan alternatif terbaik. 
2.8. Fuzzy Technique for Order Preference by Similarity to Ideal Solution(FTOPSIS)

FTOPSIS pada dasarnya sama dengan TOPSIS biasa, seperti yang sudah dijelaskan pada FSAW. Menurut Hwang dan Yoon (1981), TOPSIS didasarkan pada konsep dimana alternatif terpilih yang terbaik harus memiliki jarak sedekat mungkin dengan solusi ideal positif dan sejauh mungkin dengan solusi ideal negatif.Menurut Kusumadewi dkk. (2006), metode FTOPSIS terdiri dari langkah-langkah sebagai berikut:

1. Membuat matriks keputusan (X) yang sudah diubah dalam data fuzzy, seperti pada persamaan (1).

2. Membuat matriks keputusan yang ternormalisasi.

$r_{i j}=\frac{x_{i j}}{\sqrt{\sum_{j=1}^{n}\left(x_{i j}\right)^{2}}}$

3. Membuat matriks keputusan yang ternormalisasi terbobot.

$$
y_{i j=} \lambda_{j} \times r_{i j}
$$

4. Menentukan matriks solusi ideal positif dan matriks solusi ideal negatif.

$$
\begin{aligned}
& A^{+}=\left(y_{1}{ }^{+}, y_{2}{ }^{+}, \ldots, y_{n}{ }^{+}\right) ; y_{n}{ }^{+}=\text {kolom ke }- \text { j dari } A^{+} \\
& A^{-}=\left(y_{1}{ }^{-}, y_{2}{ }^{-}, \ldots, y_{n}{ }^{-}\right) ; y_{n}{ }^{-}=\text {kolom ke-j dari } A^{-}
\end{aligned}
$$

5. Menentukan jarak antara nilai setiap alternatif dengan matriks solusi ideal positif dan matriks solusi negatif.

$$
\begin{aligned}
& D_{i}^{+}=\sqrt{\sum_{j=1}^{n}\left(y_{i}^{+}-y_{i j}\right)^{2}} ; i=1,2, \ldots, m \\
& D_{i}^{-}=\sqrt{\sum_{j=1}^{n}\left(y_{i j}-y_{i}^{-}\right)^{2}} ; i=1,2, \ldots, m
\end{aligned}
$$

6. Menentukan nilai preferensi untuk setiap alternatif.

$V_{i}=\frac{D_{i}^{-}}{D_{i}^{-}+D_{i}^{+}} ; \mathrm{i}=1,2, \ldots, \mathrm{m}$

Alternatif yang terpilih adalah alternatif yang mempunyai nilai $V_{i}$ terbesar.

\subsection{Matrix Laboratory (MATLAB)}

Menurut Pujiyanta (2007), perangkat lunak matlab adalah sistem interaktif dengan elemen dasar basis data array yang dimensinya tidak perlu dinyatakan dengan khusus. Salah satu kemudahan matlab yaitu pembuatan antarmuka grafis. Antar muka grafis atau Graphical User Interface (GUI) merupakan tampilan grafis yang memudahkan user berinteraksi dengan perintah teks (Paulus dan Nataliani, 2007).Manfaat yang didapatkan dari Matlab antara lain perhitungan matematika, komputasi numerik, simulasi dan pemodelan, visualisasi dan analisis data, pembuatan grafik untuk keperluan sains dan teknik, serta pengembangan aplikasi, misalnya dengan memanfaatkan GUI.

\subsection{Graphical User Interface (GUI)}

Menurut Sugiharto (2006), GUIDE atau GUI builder merupakan sebuah Graphical User Interface (GUI) yang dibangun dengan obyek grafis seperti tombol button, kotak teks, slider, sumbuaxes, maupun menu.

\section{METODOLOGI PENELITIAN}

\subsection{Jenis dan Sumber Data}

Data yang digunakan adalah data sekunder yaitu data yang diperoleh dari bagian Kemahasiswaan FSM UNDIP. Data yang digunakan sebanyak 170 nama mahasiswa pendaftar beasiswa PPA tahun 2017. 


\subsection{Variabel Penelitian}

\section{Alternatif $\left(\mathbf{A}_{\mathbf{i}}\right)$}

Variabel alternatif 170 nama mahasiswa FSM UNDIP yang lolos maupun tidak lolos dalam penerimaan beasiswa PPA $\left(\mathrm{A}_{\mathrm{i}}, \mathrm{i}=1,2,3, \ldots, 170\right)$.

2. Kriteria $\left(\mathbf{C}_{\mathbf{j}}\right)$

Terdapat 6 variabel kriteria yang digunakan untuk proses penerimaan beasiswa PPA di FSM UNDIP yaitu $\mathrm{C}_{1}$ : IPK (Indeks Prestasi Komulatif); $\mathrm{C}_{2}$ : Penghasilan Orang Tua; $\mathrm{C}_{3}$ : Jumlah Sertifikat; $\mathrm{C}_{4}$ : Jumlah Tanggungan Orang Tua; $\mathrm{C}_{5}$ : Semester; $\mathrm{C}_{6}$ : Daya Listrik. C2 dan C6 merupakan atribut cost (biaya) dan C1, C3, C4, dan C5 merupakan atribut benefit (keuntungan). Tabel data fuzzy untuk setiap kriteria sebagai berikut:

Tabel 1. Kriteria IPK

\begin{tabular}{|c|c|c|}
\hline IPK & Bilangan Fuzzy & Nilai \\
\hline $3,00 \leq X \leq 3,25$ & Rendah & 0,25 \\
\hline $3,25<\mathrm{X} \leq 3,50$ & Cukup & 0,5 \\
\hline $3,50<\mathrm{X} \leq 3,75$ & Tinggi & 0,75 \\
\hline $\mathrm{X}>3,75$ & Sangat Tinggi & 1 \\
\hline
\end{tabular}

Tabel 2. Kriteria Penghasilan Orang Tua

\begin{tabular}{|c|c|c|}
\hline Penghasilan & Bilangan Fuzzy & Nilai \\
\hline $\mathrm{X} \leq \mathrm{Rp} 1.000 .000$ & Rendah & 0,25 \\
\hline $1.000 .000<\mathrm{X} \leq 3.000 .000$ & Cukup & 0,5 \\
\hline $3.000 .000<\mathrm{X} \leq 5.000 .000$ & Tinggi & 0,75 \\
\hline $\mathrm{X}>5.000 .000$ & Sangat Tinggi & 1 \\
\hline
\end{tabular}

Tabel 3.Kriteria Jumlah Sertifikat

\begin{tabular}{|c|c|c|}
\hline Jumlah Sertifikat & Bilangan Fuzzy & Nilai \\
\hline$\leq 1$ Sertifikat & Rendah & 0,25 \\
\hline 2 Sertifikat & Cukup & 0,5 \\
\hline 3 Sertifikat & Tinggi & 0,75 \\
\hline >3 Serifikat & Sangat Tinggi & 1 \\
\hline
\end{tabular}

Tabel 4. Kriteria Jumlah Tanggungan Orang Tua

\begin{tabular}{|c|c|c|}
\hline Jumlah Tanggungan OrangTua & Bilangan Fuzzy & Nilai \\
\hline$\leq 2$ anak & Rendah & 0,25 \\
\hline 3 anak & Cukup & 0,5 \\
\hline 4 anak & Tinggi & 0,75 \\
\hline$>4$ anak & Sangat Tinggi & 1 \\
\hline
\end{tabular}

Tabel 5.Kriteria Semester

\begin{tabular}{|c|c|c|}
\hline Jumlah Semester & Bilangan Fuzzy & Nilai \\
\hline $\mathrm{X} \leq 2$ & Rendah & 0,25 \\
\hline $2<\mathrm{X} \leq 4$ & Sedang & 0,5 \\
\hline $4<\mathrm{X} \leq 6$ & Tinggi & 0,75 \\
\hline $\mathrm{X}>6$ & Sangat Tinggi & 1 \\
\hline
\end{tabular}

Tabel 6. Kriteria Daya Listrik

\begin{tabular}{|c|c|c|}
\hline Jumlah Daya Listrik & Bilangan Fuzzy & Nilai \\
\hline $\mathrm{X} \leq 900$ & Rendah & 0,25 \\
\hline $900<\mathrm{X} \leq 1300$ & Sedang & 0,5 \\
\hline $1300<\mathrm{X} \leq 2200$ & Tinggi & 0,75 \\
\hline $\mathrm{X}>2200$ & Sangat Tinggi & 1 \\
\hline
\end{tabular}




\section{Bobot awal kriteria yang telah ditentukan oleh FSM}

Bobot awal yng telah ditentukan oleh FSM untuk $\mathrm{C}_{1}=0.4 ; \mathrm{C}_{2}=0.15 ; \mathrm{C}_{3}=0.2$; $\mathrm{C}_{4}=0.15 ; \mathrm{C}_{5}=0.05$ dan $\mathrm{C}_{6}=0.05$

\subsection{Langkah-Langkah Penelitian}

1. Menginput data alternatif pada kriteria masing-masing yang kemudian diubah ke dalam data fuzzydari setiap alternatif pada masing-masing kriteria.

2. Menginput bobot awal kriteria yang telah ditentukan sebelumnya oleh pelaksana.

3. Mencari bobot menggunakan pembobotanentropi

a. Normalisasi tabel data kriteria seperti pada persamaan (2)

b. Perhitungan entropi seperti pada persamaan (7)

c. Perhitungan bobot entropi seperti pada persamaan (11)

4. Fuzzy Simple Additive Weighting (FSAW)

a. Melakukan normalisasi matriks keputusan seperti pada persamaan (12).

b. Menentukan nilai preferensi untuk setiap alternatif dengan menggunakan persamaan (13).

c. Menentukan mahasiswa yang pantas menerima beasiswa PPA dengan melihat nama mahasiswa yang memiliki nilai preferensi terbesar.

5. Fuzzy Technique For Order Preference By Similarity To Ideal Solution (FTOPSIS)

a. Membuat matriks keputusan yang ternormalisasi seperti pada persamaan (14)

b. Membuat matriks keputusan yang ternormalisasi terbobot seperti pada persamaan (15).

c. Menentukan matriks solusi ideal positif dan matriks solusi ideal negatif seperti pada persamaan (16) dan (17).

d. Menentukan jarak antara nilai setiap alternatif dengan matriks solusi ideal positif dan solusi ideal negatif seperti pada persamaan (18) dan (19).

e. Menentukan nilai preferensi untuk setiap alternatif dengan menggunakan Persamaan (20).

f. Menentukan mahasiswa yang pantas menerima beasiswa PPA dengan melihat nilai preferensi terbesar.

\section{HASIL DAN PEMBAHASAN}

\subsection{Deskripsi Data}

Data yang digunakan pada penelitian merupakan data yang telah diubah ke dalam data fuzzy. $\mathrm{C}_{1}$ merupakan kriteria yang memiliki pengaruh paling besar dalam proses seleksi penerimaan beasiswa PPA berdasarkan bobot awal dari FSM. Jika nilai $\mathrm{C}_{1}$ tinggi, maka peluang untuk mendapatkan beasiswa PPA besar. Apabila terdapat nilai $\mathrm{C}_{1}$ yang sama pada alternatif satu dengan lainnya, maka mempertimbangkan alternatif manakah yang mempunyai jumlah sertifikat $\left(\mathrm{C}_{3}\right)$ lebih banyak. Setelah itu, melihat jumlah penghasilan orang tua $\left(\mathrm{C}_{2}\right)$ yang terendah dan mempunyai tanggungan orang tua $\left(\mathrm{C}_{4}\right)$ yang terbanyak.Kriteria semester $\left(\mathrm{C}_{5}\right)$ yang tertinggi dan kriteria daya listrik $\left(\mathrm{C}_{6}\right)$ melihat yang terendah.

\subsection{Pembobotan Entropi}

a. Normalisasi data

$$
d_{11}=\frac{x_{11}}{\max _{i}\left(x_{i 1}\right)}=\frac{0.5}{1}=0.5
$$




$$
\begin{aligned}
& d_{12}=\frac{x_{12}}{\max _{i}\left(x_{i 2}\right)}=\frac{0.75}{1}=0.75 \\
& \vdots \\
& d_{170 ; 6}=\frac{x_{170 ; 6}}{\max _{i}\left(x_{i 6}\right)}=\frac{0.25}{0.5}=0.5
\end{aligned}
$$

Sehingga diperoleh matriks ternormalisasi sebagai berikut :

$$
\mathbf{D}=\left[\begin{array}{cccc}
0.5 & 0.75 & \cdots & 0.5 \\
0.75 & 0.75 & \cdots & 0.5 \\
\vdots & \vdots & & \vdots \\
1 & 0.75 & \cdots & 0.5
\end{array}\right]
$$

Selanjutnya menghitung $D_{j}=\sum_{i=1}^{m} d_{i j} ; \mathrm{j}=1,2,3,4,5,6$

$D_{1=}(0.5+0.75+0.75+\ldots+1)=107.5$

$D_{2}=(0.75+0.75+1+\ldots+0.75)=118.5$

$\vdots$

$D_{6=}(0.5+0.5+0.5+\ldots+0.75)=103$

b. Menghitung nilai entropi setiap kriteria

$$
\begin{aligned}
K= & \frac{1}{\ln m}=\frac{1}{\ln (170)}=0.19471 \\
\mathrm{e}\left(d_{j}\right)= & -K \sum_{i=1}^{m} \frac{d_{i j}}{D_{j}} \ln \frac{d_{i j}}{D_{j}} ; i=1,2, \ldots, 170 ; j=1,2,3,4,5,6 \\
\mathrm{e}\left(d_{1}\right)= & -(0.19471)\left\{\left(\frac{0.5}{107.5} \ln \frac{0.5}{107.5}\right)+\left(\frac{0.75}{107.5} \ln \frac{0.75}{107.5}\right)+\ldots+\right. \\
& \left.\left(\frac{1}{107.5} \ln \frac{1}{107.5}\right)\right\}=0.98465 \\
\mathrm{e}\left(d_{2}\right)= & -(0.19471)\left\{\left(\frac{0.75}{118.5} \ln \frac{0.75}{118.5}\right)+\left(\frac{0.75}{118.5} \ln \frac{0.75}{118.5}\right)+\ldots+\right. \\
& \left.\left(\frac{0.75}{118.5} \ln \frac{0.75}{118.5}\right)\right\}=0.99132 \\
\mathrm{e}\left(d_{6}\right)= & -(0.19471)\left\{\left(\frac{0.5}{103} \ln \frac{0.5}{103}\right)+\left(\frac{0.5}{103} \ln \frac{0.5}{103}\right)+\ldots+\right. \\
& \left.\left(\frac{0.5}{103} \ln \frac{0.5}{103}\right)\right\}=0.99023
\end{aligned}
$$

c. Perhitungan bobot entropi

Rumus perhitungan bobot entropi dengan kombinasi bobot awal adalah sebagai berikut :

$\lambda_{j}=\frac{\bar{\lambda}_{\mathrm{j}} \cdot w_{j}}{\sum_{j=1}^{n} \bar{\lambda}_{\mathrm{j}} \cdot \mathrm{w}_{\mathrm{j}}}$

dengan $\bar{\lambda}_{\mathrm{j}}=\frac{1}{n-E}\left\{1-e\left(d_{j}\right)\right\}$ danw $_{\mathrm{j}}$ adalah bobot awal yang telah ditentukan sebelumnya oleh pelaksana.

$$
\begin{aligned}
& \bar{\lambda}_{\mathrm{j}}=\frac{1}{n-E}\left\{1-e\left(d_{j}\right)\right\} ; \mathrm{j}=1,2,3,4,5,6 \\
& E=\sum_{j=1}^{6} e\left(d_{j}\right)=0.985+0.991+\cdots+0.990=5.9382
\end{aligned}
$$




$$
\begin{aligned}
& \bar{\lambda}_{1}=\frac{1}{6-5.9382}(1-0.98465)=0.24818 \\
& \bar{\lambda}_{2}=\frac{1}{6-5.9382}(1-0.99132)=0.14041 \\
& \vdots \\
& \bar{\lambda}_{6}=\frac{1}{6-5.9382}(1-0.99023)=0.15804
\end{aligned}
$$

Sehingga diperoleh nilai bobot entropi setiap kriteria $\left(\lambda_{j}\right)$ sebagai berikut: $\lambda_{1}=$ $0.52804 ; \lambda_{2}=0.11203 ; \lambda_{3}=0.15831 ; \lambda_{4}=0.11788 ; \lambda_{5}=0.04171 ; \lambda_{6}=0.04203$

4.3 Penentuan Penerima Beasiswa PPA tahun 2017 dengan Metode FuzzySimple Additive Weighting (FSAW)

a. Normalisasi data

Atribut cost /biaya yaitu C2 dan C6 sedangkan C1, C3, C4, dan C5 yaitu atribut benefit/keuntungan. Maka, perhitungan $r_{i j}$ sebagai berikut :

$$
\begin{aligned}
& r_{11}=\frac{x_{11}}{\max _{i}\left(x_{i 1}\right)}=\frac{0.5}{1}=0.5 \\
& r_{12}=\frac{\min _{i}\left(x_{12}\right)}{x_{i j}}=\frac{0.5}{0.75}=0.667 \\
& \vdots \\
& r_{170 ; 6}=\frac{\min _{i}\left(x_{170 ; 6}\right)}{x_{i j}}=\frac{0.25}{0.25}=1
\end{aligned}
$$

Sehingga diperoleh matriks ternormalisasi $(\mathbf{R})$ adalahsebagai berikut:

$$
\mathbf{R}=\left[\begin{array}{cccc}
0.5 & 0.667 & \ldots & 1 \\
0.75 & 0.667 & \cdots & 1 \\
\vdots & \vdots & & \vdots \\
1 & 0.667 & \cdots & 1
\end{array}\right]
$$

b. Menentukan nilai preferensi $\left(\mathrm{V}_{\mathrm{i}}\right)$ setiap alternatif dengan rumus:

$$
\begin{gathered}
V_{1}=\{(0.52804 \\
+\quad 0.5)+(0.11203 \times 0.667)+(0.15831 \times 0.333) \\
\quad \times 1)\}=0.4832 \\
V_{2}=\{(0.52804 \times 0.75)+(0.11203 \times 0.667)+(0.15831 \times 0.333) \\
+\quad(0.11788 \times 0.333)+(0.04171 \times 1) \\
\quad+(0.04203 \times 1)=0.6465 \\
V_{170}=\{(0.52804 \times 1)+(0.11203 \times 0.667)+(0.15831 \times 0.333) \\
\quad+(0.11788 \times 0.333)+(0.04171 \times 1) \\
+(0.04203 \times 1)=0.7785
\end{gathered}
$$

c. Mengurutkan nilai preferensi $\left(V_{i}\right)$ dari yang terbesar hingga terkecil.

4.4 Penentuan Penerima Beasiswa PPA tahun 2017 dengan Metode FuzzyTechnique for Order Preference by Similarity to Ideal Solution (FTOPSIS)

a. Membuat matriks keputusan ternormalisasi

$$
\begin{aligned}
& r_{11}=\frac{0.5}{\sqrt{(0.5)^{2}+(0.75)^{2}+(0.75)^{2}+\cdots+(1)^{2}}}=0.0567 \\
& r_{12}=\frac{0.75}{\sqrt{(0.75)^{2}+(0.75)^{2}+(1)^{2}+\cdots+(0.75)^{2}}}=0.079
\end{aligned}
$$




$$
r_{170 ; 6}=\frac{0.25}{\sqrt{(0.25)^{2}+(0.25)^{2}+(0.25)^{2}+\cdots+(0.25)^{2}}}=0.0599
$$

Sehingga diperoleh matriks keputusan ternormalisasi $(\mathbf{R})$ adalah sebagai berikut:

$$
\mathbf{R}=\left[\begin{array}{cccc}
0.0567 & 0.079 & \cdots & 0.0599 \\
0.0849 & 0.079 & \cdots & 0.0599 \\
\vdots & \vdots & & \vdots \\
0.1133 & 0.079 & \cdots & 0.0599
\end{array}\right]
$$

b. Membuat matriks ternormalisasi terbobot $(\mathbf{Y})$

$$
\begin{aligned}
& y_{11=} \lambda_{1} \times r_{11}=0.52804 \times 0.0567=0.0299 \\
& y_{12=} \lambda_{2} \times r_{12}=0.11203 \times 0.079=0.0088 \\
& \vdots \\
& y_{170 ; 6=} \lambda_{6} \times r_{170 ; 6}=0.04203 \times 0.0599=0.0025
\end{aligned}
$$

Sehingga diperoleh matriks ternormalisasi terbobot $(\mathbf{Y})$ sebagai berikut:

$$
\mathbf{Y}=\left[\begin{array}{cccc}
0.0299 & 0.0088 & \cdots & 0.0025 \\
0.0449 & 0.0088 & \cdots & 0.0025 \\
\vdots & \vdots & & \vdots \\
0.0598 & 0.0088 & \cdots & 0.0025
\end{array}\right]
$$

c. Menentukan Matriks Solusi Ideal Positif dan Matriks Solusi Ideal Negatif

Berdasarkan matriks (Y) diperoleh nilai solusi ideal positif $\left(A^{+}\right)$adalah $A^{+}=$ $(0.0598 ; 0.0059 ; 0.0308 ; 0.0223 ; 0.0042 ; 0.0025)$ dan nilai solusi ideal negatif $\left(A^{-}\right)$adalah $A^{-}=(0.015 ; 0.012 ; 0.01 ; 0.007 ; 0.001 ; 0.005)$

d. Menentukan jarak antara nilai setiap alternatif dengan solusi ideal positif dan solusi ideal negatif.

Tabel 8. Nilai Jarak antara Alternatif dengan $D_{i}^{+}$dan $D_{i}^{-}$

\begin{tabular}{|c|c|c|}
\hline Alternatif & $D_{i}^{+}$ & $D_{i}^{-}$ \\
\hline 1 & 0.03946 & 0.01545 \\
\hline 2 & 0.0296 & 0.03033 \\
\hline$\vdots$ & $\vdots$ & $\vdots$ \\
\hline 170 & 0.02554 & 0.04515 \\
\hline
\end{tabular}

e. Menentukan Nilai Preferensi untuk setiap Alternatif

$$
\begin{aligned}
& V_{1}=\frac{0.0154}{0.0154+0.0395}=0.2814 \\
& V_{2}=\frac{0.0303}{0.0303+0.0296}=0.5061 \\
& \vdots \\
& V_{170}=\frac{0.0451}{0.0451+0.0255}=0.6387
\end{aligned}
$$

f. Mengurutkan nilai preferensi $\left(V_{i}\right)$ setiap alternatif dari terbesar hingga terkecil.

\subsection{Perbandingan Hasil Perhitungan antara Metode FSAW, FTOPSIS dan FSM}

Dalam perhitungan menggunakan metode FSAW dn FTOPSIS, dapat disimpulkan bahwa pada hasil perhitungan kedua metode menghasilkan peringkat pertama hingga ketiga sama. Alternatif ke-81 peringkat 1 berdasarkan metode FSAW dan FTOPSIS terdapat pula di hasil penentuan FSM, walaupun peringkatnya tidak sama yaitu pada peringkat 55 . Sedangkan untuk alternatif ke-95 dan ke-122 menurut FSM tidak masuk pada 76 terbaik/tidak lolos.Alternatif ke-95 dan ke-122 seharusnya pantas mendapatkan beasiswa PPA dikarenakan nilai IPK yang tinggi yaitu 3.83 dan 3.76.Penyeleksian penerima beasiswa 
PPA yang dilakukan oleh FSM kurang baik, karena tidak sesuai dengan bobot kriteria yang telah ditentukan sebelumnya oleh FSM.

4.6 Tutorial GUI Matlab untuk Metode FSAW dan FTOPSIS

a. Klik tombol RUN pada Matlab

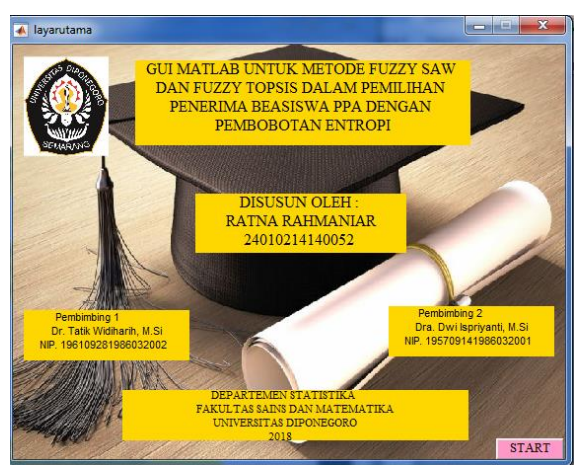

c. Klik tombol MULAI ANALISIS

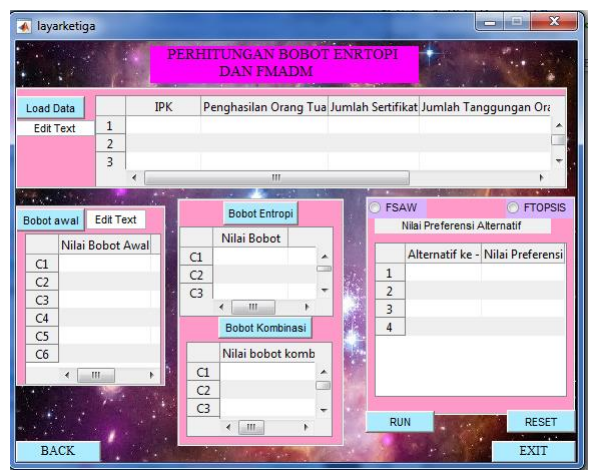

e. Klik tombol Bobot Awal

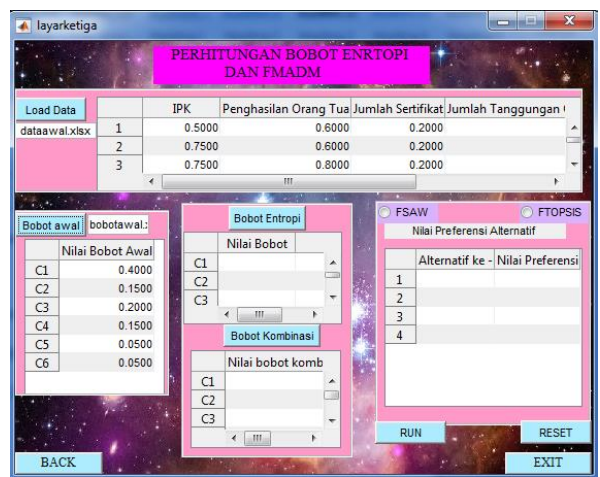

g. Klik tombol Bobot Kombinasi

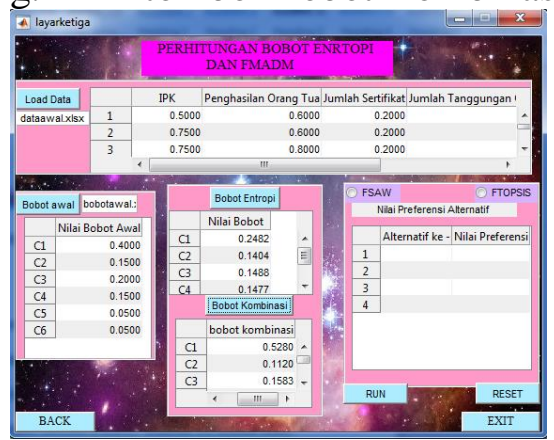

b. Klik tombol START



d. Klik Load Data

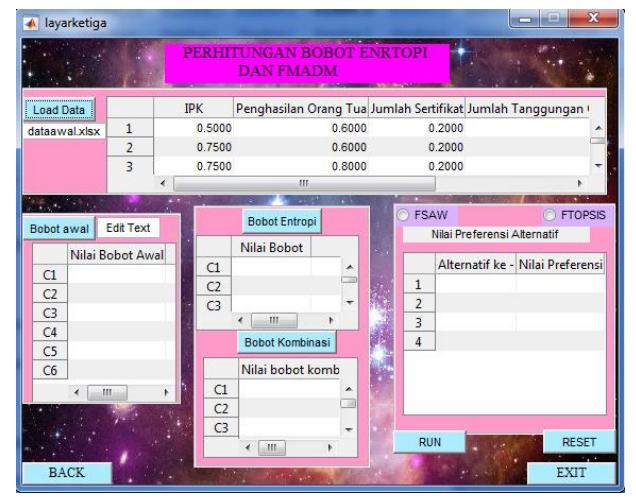

f. Klik tombol Bobot Entropy

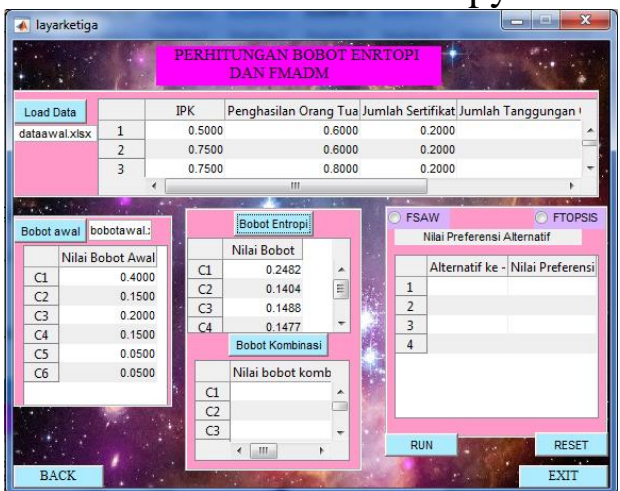

h. Klik tombol FSAW lalu klik RUN

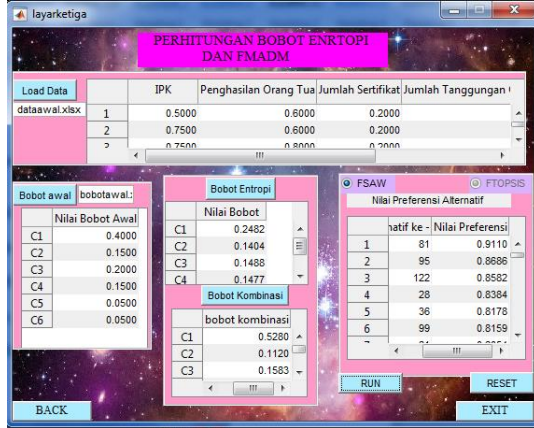


i. Klik tombol RESET

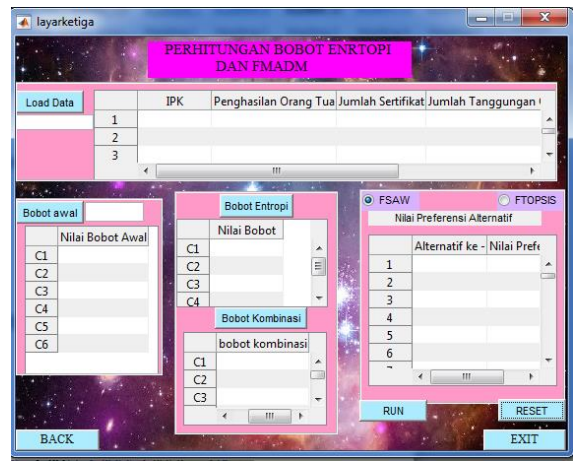

k. Klik tombol EXIT

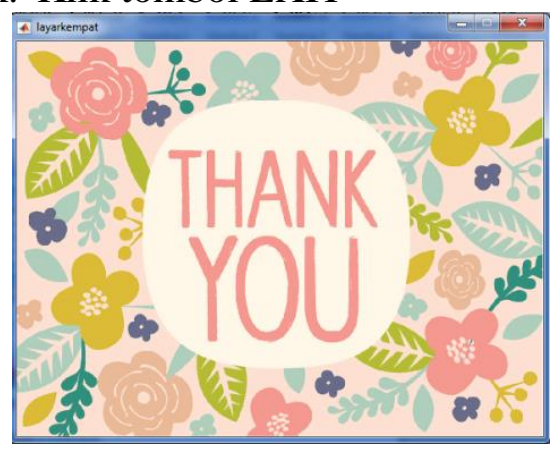

j. Klik tombol FTOPSIS lalu klik RUN



\section{KESIMPULAN}

Berdasarkan pada hasil analisis penelitian yang telah dilakukan, dapat disimpulkan beberapa hal sebagai berikut:

1. Nilai bobot entropi yang diperoleh adalah $\lambda_{1}=0.52804 ; \lambda_{2}=0.11203 ; \lambda_{3}=0.15831$; $\lambda_{4}=0.11788 ; \lambda_{5}=0.04171 ; \lambda_{6}=0.04203$. Nilai bobot tersebut baik untuk digunakan dalam proses penyeleksian penerima beasiswa PPA.

2. Metode FSAW dan FTOPSIS lebih baik digunakan untuk penyelesaian masalah pemilihan mahasiswa yang pantas menerima beasiswa PPA daripada penentuan dari FSM, dikarenakan FSM hanya melakukan penyeleksian secara manual dengan melihat berkas-berkas yang telah dikumpulkan oleh pendaftar selanjutnya menyeleksi berdasarkan bobot yang telah ditentukan sebelumnya.

3. Alternatif yang berhak menerima beasiswa PPA menurut metode FSAW dan FTOPSIS sebesar $96 \%$ sama hasilnya, walaupun urutan perankingnya tidak sama. Sedangkan, hasil alternatif yang berhak menerima beasiswa PPA berdasarkan penentuan dari FSM hanya $39 \%$ hasil yang sama dengan metode FSAW dan $42 \%$ hasil yang sama dengan metode FTOPSIS.

\section{DAFTAR PUSTAKA}

Arikunto, S. 2006. Prosedur Penelitian Suatu Pendekatan Praktik Edisi Revisi VI. Jakarta : Rineka Cipta.

Ariyadi, B. D. 2013. Sistem Pendukung Keputusan Seleksi Penerima Beasiswa pada SMA 2 Boja dengan Menggunakan Metode Analytical Hierarchy Process (AHP).

Hwang, C. L., \& Yoon, K. 1981. Multiple-Attribute Decision Making - Methods and Applications A State of The Art Survey. New York: Springer Verlag.

Jamila dan Hartati, S. 2011. Sistem Pendukung Keputusan Pemilihan Subkontrak menggunakan Metode Entropy dan TOPSIS.IJCCS : 5 (2), 12-19. 
Kusumadewi, S., Hartati, S., Harjoko, A., dan Wardoyo, R. 2006. Fuzzy MultiAttribute Decision Making (FUZZY MADM). Yogyakarta: Graha Ilmu.

Margono,S. 2004. Metodologi Penelitian Pendidikan. Jakarta : Rineka Cipta.

Paulus, E. dan Nataliani, Y. 2007.GUI Matlab disertai Studi Kasus. Yogyakarta: ANDI

Putra, A. dan Hardiyanti, D. Y. 2011.Penentuan Penerima Beasiswa dengan menggunakan Fuzzy Multi-Attribute Decision Making. JSI: Vol. 3, No.1.

Sugiyono.2001. Metode Penelitian, Bandung: CV Alfa Beta.

Sugiyono.2010. Metode Penelitian Pendidikan Pendekatan Kuantitatif, kualitatif, dan $R \& D$. Bandung: Alfabeta

Triyanti, V. dan Gadis, M. T. 2008.Pemilihan Supplier untuk Industri Makanan menggunakan Metode Promethee.Journal of Logistics and Supply Chain Management.Vol. 1, No. 2, hal.83-92. 